\title{
Steroid production by dispersed cells from fetal membranes and intrauterine tissues of sheep*
}

\author{
S. G. A. Power and J. R. G. Challis
}

Research Institute, St. Joseph's Hospital, University of Western Ontario, Departments of Obstetrics/Gynaecology and Physiology, 268 Grosvenor Street, London, Ontario, Canada N6A 4 V2

\begin{abstract}
Summary. The hypothesis was examined that the fetal membranes and the endometrium and myometrium of pregnant sheep have the ability to produce oestrogens and progesterone from exogenous precursors, and that this capacity might change during the course of pregnancy, and in relation to the onset of parturition. Cells were dispersed from samples of myometrium, endometrium, allantois, chorion and amnion from sheep at Day 50, Days 130-135 of pregnancy, and at term, in labour, and were incubated in the presence of pregnenolone and $20 \alpha$-dihydroprogesterone as potential precursors for progesterone production, and oestrone sulphate and androstenedione as potential precursors for oestrogen production. In addition, the metabolism of radioactive progesterone and oestrone sulphate by the dispersed cells was examined.

Pregnenolone was converted to progesterone in significant amounts by dispersed cells from chorion and endometrium only. At Day 130 and at term this conversion was blocked by the addition of trilostane, an inhibitor of $3 \beta$-hydroxysteroid dehydrogenase activity. There was no significant change in the net production of progesterone from exogenous pregnenolone with gestation. $20 \alpha$-Dihydroprogesterone was converted to progesterone by all tissues, and at each stage of gestation. Formation of progesterone from $20 \alpha$-dihydroprogesterone was invariably greater than that from pregnenolone, but did not change with pregnancy. Oestrone sulphate was converted to oestrone and oestradiol by all tissues. In the myometrium and chorion this conversion was lower at term than at Day 50 of pregnancy. In contrast, there was very little conversion of androstenedione to unconjugated oestrogen, minimal activity being demonstrable only in dispersed cells from the chorion in some preparations. Radioactive progesterone was converted to radiochemically pure $17 \alpha$-hydroxyprogesterone by chorion, and to radiochemically pure $20 \alpha$-dihydroprogesterone by amnion, chorion, allantois and endometrium obtained at term pregnancy. At term $\left[{ }^{3} \mathrm{H}\right]$ oestrone sulphate was converted to radiochemically pure oestrone by all tissues.

We conclude that there is a tissue-specific distribution of different steroid metabolizing enzyme activities in the fetal membranes and intrauterine tissues of pregnant sheep. Of the substrates examined, 20a-dihydroprogesterone and oestrone sulphate were preferred for progesterone and oestrogen production, respectively. The widespread steroidogenic enzyme activity in the fetal membranes and intrauterine tissues of the pregnant sheep raises the possibility that there may be local modulation of steroid formation in vivo, with attendant consequences on the later events leading to parturition.
\end{abstract}

\section{Introduction}

In previous studies we have demonstrated changes in the concentrations of progesterone and oestrogens in the intrauterine tissues (endometrium and myometrium) and in the fetal membranes

*Reprint requests to Professor J. R. G. Challis. 
(amnion, chorion and allantois) of sheep during late pregnancy, and after labour induced by the administration of ACTH to the fetus in utero (Power \& Challis, 1987a, b). In particular, labour was associated with a fall in progesterone and a rise in the concentration of oestrogen in the endometrium and myometrium, reflecting changes in the maternal plasma concentrations of the steroids. In the fetal membranes oestrogen and progesterone concentrations both rose in late pregnancy. Homogenates of sheep fetal membranes also have the ability to produce progesterone from pregnenolone and this activity is inhibited by several steroids, including oestrone and oestradiol (Power \& Challis, 1983). Because the fetal membranes are also major sites of prostaglandin production in late pregnancy (Olson et al., 1984), and steroids may modulate prostaglandin biosynthesis (see Thorburn \& Challis, 1979), paracrine or autocrine control of prostaglandin output in the fetal membrane by a locally produced steroid is possible. Activities of $5 \alpha$-reductase, $20 \alpha$-hydroxysteroid dehydrogenase, oestrone sulphatase and 17 $\beta$-hydroxysteroid dehydrogenase are present in subcellular fractions of the endometrium and myometrium (Rossier \& Pierrepoint, 1974a, b; Dwyer \& Robertson, 1980). However, in none of the above studies has the potential been established for steroid production by intact cells, at different stages of pregnancy.

In the present experiments we have examined the hypothesis that the fetal membranes and the endometrium and myometrium of pregnant sheep have the ability to produce progesterone and oestrogen from endogenous or exogenous precursors, and that the output of these steroids might change during pregnancy or in relation to parturition. Intact dispersed cells were used to measure progesterone production from two potential precursors, namely pregnenolone and $20 \alpha$ dihydroprogesterone, and to examine unconjugated oestrogen production from oestrone sulphate and from androstenedione.

\section{Materials and Methods}

Animals. Twenty-three sheep of known gestational age were used. Tissues were obtained from animals at Day 50 of pregnancy ( 6 ewes), Days 130-135 of pregnancy ( 7 ewes), and term (10 ewes). The animals at term were in active labour as assessed by the intrauterine pressure recording from an open-ended catheter placed in the amniotic cavity (Lye et al., 1983).

Cell dispersion. Samples of myometrium, endometrium, allantois, chorion and amnion were obtained from pregnant sheep under general anaesthesia as described by Power \& Challis (1987b). The tissues were minced and incubated with $0.1 \%$ collagenase in Dulbecco's phosphate buffer at $37^{\circ} \mathrm{C}$ for $1 \mathrm{~h}$. Cells were harvested by centrifugation at $500 \mathrm{~g}$ for $20 \mathrm{~min}$, and washed in Krebs' phosphate buffer $(\mathrm{pH}, 7 \cdot 4)$ containing $0.2 \%$ glucose and $0.5 \%$ albumin. The cells were then centrifuged again, and resuspended in Krebs' buffer containing glucose and albumin. Greater than $90 \%$ of the cells were viable, as indicated by their ability to exclude trypan blue dye.

Because it has been shown that fetal sheep red blood cells possess $20 \alpha$-hydroxysteroid dehydrogenase activity, and can convert progesterone to 20a-dihydroprogesterone (Nancarrow \& Seamark, 1968), it was important to establish that enzyme activities in the vascular chorionic tissue were not attributable to contamination by fetal red cells. In preliminary studies, the chorionic cells were separated from fetal red blood cells by applying the cell dispersions to a discontinuous gradient of Percoll (10,20 and $40 \%$ volumes). The gradients were centrifuged at $500 \mathrm{~g}$ for $20 \mathrm{~min}$. The chorionic cells equilibrating in $10 \%$ and $20 \%$ Percoll were harvested; red blood cells sedimented as a pellet into $40 \%$ Percoll.

Cell numbers were measured in each experiment by using a Coulter counter. It was established in preliminary studies that this method gave results similar to those obtained using a haemocytometer.

Cell incubations. For each tissue dispersed cells $\left(5 \times 10^{4}\right.$ to $1 \times 10^{6}$ cells $\left./ \mathrm{ml}\right)$ were incubated with or without substrate in Krebs' phosphate buffer containing glucose and albumin for $4 \mathrm{~h}$ at $37^{\circ} \mathrm{C}$. In addition, tubes containing substrate alone, without cells, were incubated to obtain blank values for subsequent radioimmunoassays. The incubations were terminated by freezing at $-20^{\circ} \mathrm{C}$.

Output of progesterone. The net accumulation (output) of progesterone was measured from endogenous precur-

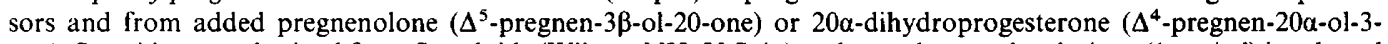
one). Steroids were obtained from Steraloids (Wilton, NH, U.S.A.) and stored as stock solutions $(1 \mathrm{mg} / \mathrm{ml}$ ) in ethanol at $-20^{\circ} \mathrm{C}$. Incubations were performed in the presence of added steroid at $100 \mathrm{ng} / \mathrm{ml}$. In some incubations with chorion or endometrial cell preparations, progesterone output was determined in the presence of pregnenolone and trilostane (10 mg/ml; Sterling-Winthrop Ltd, Aurora, Ontario, Canada), an inhibitor of $3 \beta$-hydroxysteroid dehydrogenase ( $3 \beta$-HSD). The net accumulation of progesterone from endogenous or exogenous substrate was calculated by subtracting the progesterone concentration in the cells + medium at the start of the incubation $(0 \mathrm{~h})$ from the concen- 
tration at the end of the incubation period $(t=4 \mathrm{~h})$. Progesterone was measured by a radioimmunoassay that has been validated extensively, as reported elsewhere (Power \& Challis, 1987a). The net accumulation of progesterone is expressed as $\mathrm{pg} / 10^{5}$ cells $/ 4 \mathrm{~h}$.

Output of oestrogens. The net accumulation of oestrone and oestradiol-17 $\beta$ was determined from endogenous precursors and from added oestrone sulphate $\left(1,3,5(10)\right.$-oestratrien-3-ol-17-one sulphate) or androstenedione $\left(\Delta^{4}\right.$ androsten-3,17-dione). Oestrone sulphate was a gift from Dr R. Hobkirk (Department of Biochemistry, University of Western Ontario) and was stored in methanol at $-70^{\circ} \mathrm{C}$. Both substrates were added at $100 \mathrm{ng} / \mathrm{ml}$. Oestrone and oestradiol-17 $\beta$ were measured by RIA using antibodies and procedures that have been described and validated by us previously (Power \& Challis, 1987b). The purity of oestrone formed from androstenedione was assessed by cochromatographing the oestrone from pooled incubations of each tissue with purified $\left[{ }^{3} \mathrm{H}\right]$ oestrone using microcelite columns, as described by us (Power \& Challis, 1987b). The net accumulation of oestrone and oestradiol-17 $\beta$ was expressed as $\mathrm{pg} / 10^{5}$ cells $/ 4 \mathrm{~h}$.

In additional experiments, dispersed cells were obtained from the fetal membranes, endometrium and myometrium of two animals in late pregnancy. Incubations were conducted in quadruplicate for different times between $0-8 \mathrm{~h}$ in the presence of $100 \mathrm{ng} 20 \mathrm{a}$-dihydroprogesterone, pregnenolone or oestrone sulphate $/ \mathrm{ml}$, or for $4 \mathrm{~h}$ in the presence of different concentrations $(10-500 \mathrm{ng} / \mathrm{ml})$ of the substrates. The production of progesterone and oestrone was compared with that by collagenase-dispersed cells obtained as above from the fetal component of the cotyledons.

Metabolism of radioactive substrates. $\left[{ }^{3} \mathrm{H}\right]$ Progesterone (sp. act. $40-60 \mathrm{Ci} / \mathrm{mmol}$ ) and $\left[{ }^{3} \mathrm{H}\right]$ oestrone-3-sulphate (sp. act. $40-60 \mathrm{Ci} / \mathrm{mmol}$ ) were obtained from NEN Ltd (Boston, MA, U.S.A.). The purity of $\left[{ }^{3} \mathrm{H}\right]$ progesterone was checked by thin-layer chromatography (t.l.c.) in the system chloroform:diethyl ether $(10: 3, \mathrm{v} / \mathrm{v})$ before use. Incubations were performed with intact cells in the presence of $\sim 0.5 \mu \mathrm{Ci}$ substrate. Blank tubes containing radioactive substrate but no cells were included in each incubation. The radioactivity isolated from these blank incubations by t.l.c. in zones corresponding in mobility to potential product steroids was subtracted before calculating conversions.

Incubations with radioactive substrates were performed for $4 \mathrm{~h}$ at $37^{\circ} \mathrm{C}$ in Krebs' buffer, $\mathrm{pH} 7 \cdot 4$ containing glucose and albumin as above. For analysis, the products were thawed on ice, and steroids were extracted with diethyl ether $(2 \times 5 \mathrm{ml})$. The ether extracts were dried under nitrogen, and resuspended in $40 \mu \mathrm{l}$ ethanol for application to t.l.c. plates. The extracts from incubations with $\left[{ }^{3} \mathrm{H}\right]$ progesterone were chromatographed in the system chloroform:diethyl ether $(10: 3 \mathrm{v} / \mathrm{v})$, and those from incubations with $\left[{ }^{3} \mathrm{H}\right]$ oestrone sulphate were developed in the system cyclohexane: ethyl acetate $(60: 40 \mathrm{v} / \mathrm{v})$. Appropriate standards $(40 \mu \mathrm{g})$ were chromatographed on adjacent lanes or on additional t.l.c. plates and visualized by u.v. absorption at $240 \mathrm{~nm}$ or in the presence of iodine vapour as appropriate in order to calculate relative retention values $\left(R_{\mathrm{F}}\right)$. In most experiments bands of silica gel $(1 \mathrm{~cm})$ between the origin and solvent front were scraped off directly into scintillation vials containing $4 \mathrm{ml}$ toluene with $12 \%$ glacial acetic acid and $0.5 \mathrm{~g}$ $\mathrm{PPO} / 100 \mathrm{ml}$, shaken, and counted in a liquid scintillation counter.

In additional incubations with $\left[^{3} \mathrm{H}\right]$ progesterone, the silica gel bands were eluted with ethyl acetate $(2 \times 1 \mathrm{ml})$, dried, and resuspended in ethanol $(200 \mu \mathrm{l})$. An aliquant $(50 \mu \mathrm{l})$ was obtained for the measurement of total radioactivity. The remaining material in those fractions corresponding to the peaks of radioactivity was purified further by HPLC. $\left[{ }^{14} \mathrm{C}\right]$ Progesterone $\left(\sim 10000\right.$ d.p.m.) and steroids $(10 \mu \mathrm{g})$ appropriate for the $R_{\mathrm{F}}$ values of the separate fractions were added in ethanol. The ethanol was dried and the steroid was resuspended in methanol $(500 \mu 1)$. A sample $(200 \mu \mathrm{l})$ was taken for counting, and a second sample $(20 \mu \mathrm{l})$ was applied to an RP-8 HPLC column (Hewlett-Packard Ltd) and eluted with $60 \%$ methanol in distilled water. The elution of non-radioactive steroids was monitored by u.v. absorbance at $240 \mathrm{~nm}$. Eluates $(0.5 \mathrm{ml})$ were collected every minute, and the radioactivity was counted.

The radiochemical purity of $17 \alpha$-hydroxyprogesterone and $20 \alpha$-dihydroprogesterone formed from $\left[{ }^{3} \mathrm{H}\right]$ progesterone and separated by t.l.c. in $100 \%$ chloroform was assessed by repeated recrystallizations with authentic steroid from ethanol:water. The radiochemical purity of $\left[{ }^{3} \mathrm{H}\right]$ oestrone formed from $\left({ }^{3} \mathrm{H}\right]$ oestrone sulphate was assessed by adding purified $\left[{ }^{14} \mathrm{C}\right]$ oestrone to the t.l.c. eluates, and then determining the ${ }^{3} \mathrm{H}:{ }^{14} \mathrm{C}$ ratio in successive recrystallizations from ethanol:water with authentic oestrone.

Data analysis. All results are presented as mean \pm s.e.m. When appropriate differences in steroid production or conversion at each gestational age were assessed by one-way analysis of variance. The data were transformed logarithmically when Bartlett's test revealed heterogeneity of variance. Significant differences between mean values were sought using Duncan's multiple range test at $P<0.05$.

\section{Results}

\section{Output of progesterone}

There was no net accumulation of progesterone from endogenous substrates at any state of pregnancy. The accumulation of progesterone from pregnenolone (Fig. 1) or 20a-dihydroprogesterone (data not shown) was time- and dose-dependent by dispersed cells from chorion, 

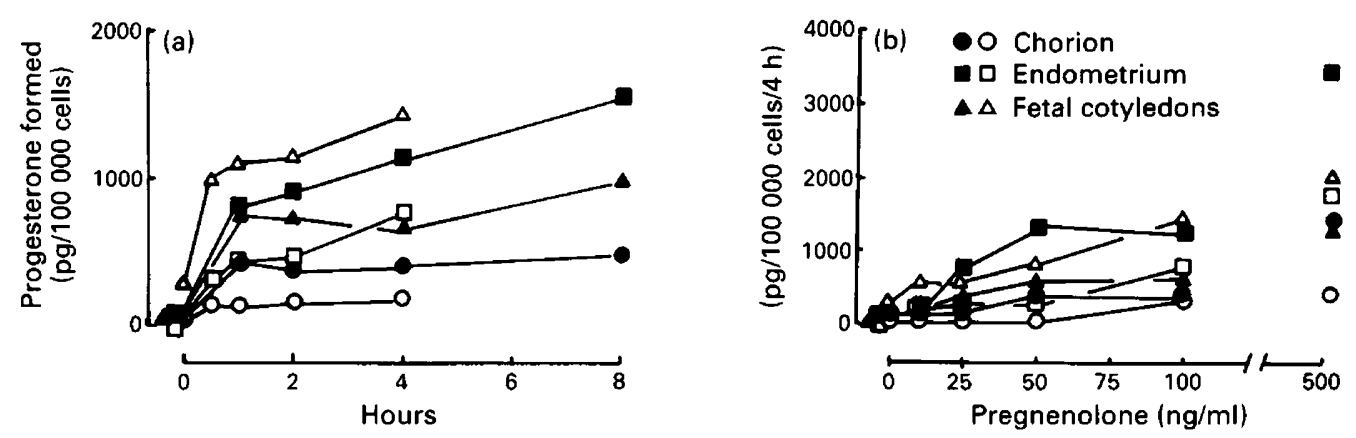

Fig. 1. The net accumulation of progesterone (a) with time after addition of $100 \mathrm{ng}$ pregnenolone $/ \mathrm{ml}$ and, (b) with various substrate (pregnenolone) concentrations during 4-h incubations. Experiments were performed with dispersed cells from chorion, endometrium, and fetal cotyledons from each of 2 sheep (solid and open symbols respectively). Each point is the mean of quadruplicate observations. The s.e.m. values are omitted for clarity, but in general were within the figure size of the datum points.

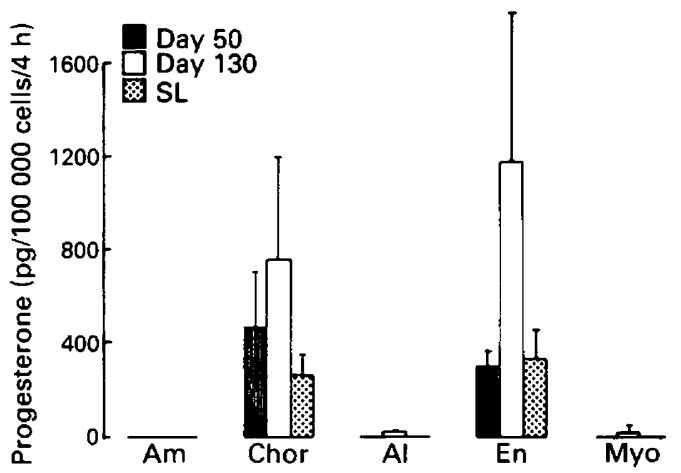

Fig. 2. The net output of progesterone from pregnenolone by dispersed cells from amnion (Am), chorion (Chor), allantois (Al), endometrium (En) and myometrium (Myo) obtained from sheep at Days 50 and 130 of pregnancy and at spontaneous labour (SL). Each value is the mean \pm s.e.m. for the number of observations indicated in the text.

endometrium and the fetal cotyledons prepared from two separate sheep at term. Exogenous pregnenolone was converted to progesterone ( $3 \beta$-HSD activity) by cells from chorion and endometrium at all stages of gestation. In contrast, progesterone formation was either not detectable or was minimal by cells from amnion, allantois or myometrium at any time in pregnancy (Fig. 2). The conversion of pregnenolone to progesterone by endometrium and chorion cells at Day 130 and at term was reduced by trilostane, an inhibitor of $3 \beta$-HSD activity $(P<0.05$; Fig. 3 ). Although the mean conversion of pregnenolone to progesterone was higher in chorion and endometrial cells at Day 130 than at Day 50 or at term, these differences were not statistically significant $(P>0.05)$. The formation of progesterone from pregnenolone in chorion cells was similar after Percoll separation, indicating that enzyme activities associated with any contaminating red blood cells did not alter the net output of progesterone in unseparated cell preparations. 


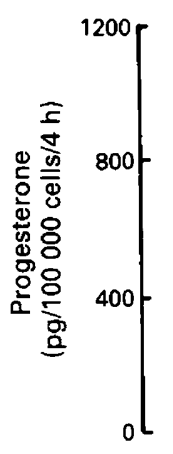

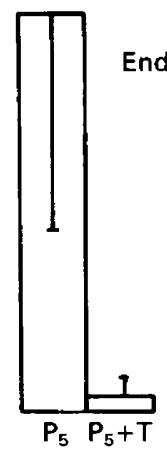

Day 130
Endometrium

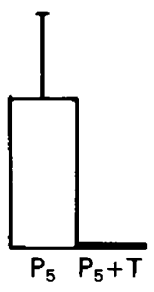

$S L$

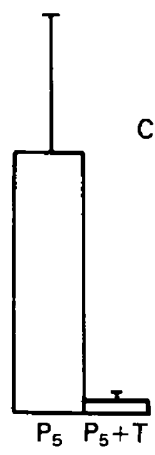

Day 130
Chorion

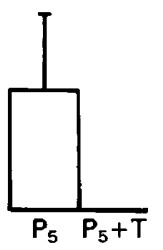

$\mathrm{SL}$

Fig. 3. The output of progesterone from pregnenolone by dispersed cells from endometrium and chorion obtained from sheep at Day 130 of pregnancy and at spontaneous labour (SL). Incubations were performed in the presence of $100 \mathrm{ng}$ pregnenolone alone $\left(\mathrm{P}_{5}\right)$ or pregnenolone + trilostane $\left(P_{5}+T\right)$. Each value is the mean \pm s.e.m. for the number of observations indicated in the text.

Table 1. Specific activities of immunoreactive progesterone produced from $20 \alpha$-dihydroprogesterone by dispersed cells of amnion, chorion and endometrium

\begin{tabular}{lccc}
\hline & \multicolumn{3}{c}{ Specific activity (c.p.m./mg) } \\
\cline { 2 - 4 } Tissue & $\begin{array}{c}\text { Gestational } \\
\text { age }\end{array}$ & $\begin{array}{c}\text { After } \\
\text { extraction } \\
\text { without } \\
\text { chromatography }\end{array}$ & $\begin{array}{c}\text { After } \\
\text { extraction } \\
\text { with } \\
\text { chromatography }\end{array}$ \\
\hline Amnion & Day 50 & 1.06 & 0.99 \\
& Day 130 & 1.19 & 1.16 \\
Chorion & Term & 1.44 & 2.04 \\
& Day 50 & 1.03 & 0.94 \\
Endometrium & Day 130 & 1.26 & 1.09 \\
& Term & 0.45 & 0.41 \\
& Day 50 & 0.33 & 0.31 \\
& Day 130 & 1.07 & 1.10 \\
& Term & 1.89 & 1.52 \\
\hline
\end{tabular}

Cells from all tissues converted $20 \alpha$-dihydroprogesterone to progesterone (20 $\alpha$-HSD activity) at each gestational age. Table 1 compares the specific activities of progesterone formed from $20 \alpha$ dihydroprogesterone and measured directly, compared to measurements made after extraction and purification by micro-celite chromatography. In amnion, chorion and endometrium, the tissues with greatest conversion of $20 \alpha$-dihydroprogesterone to progesterone, there was good agreement between the measurements made with or without chromatography, thereby supporting the authenticity of these progesterone measurements. At each time in pregnancy the formation of progesterone from $20 \alpha$-dihydroprogesterone by amnion, chorion and endometrium was similar and significantly greater than the conversion by dispersed cells from the allantois and myometrium $(P<0.05$; Fig. 4). However, within the individual tissues there was no effect of gestational age on the conversion of $20 \alpha$-dihydroprogesterone to progesterone $(P>0.05 ;$ Fig. 4). 

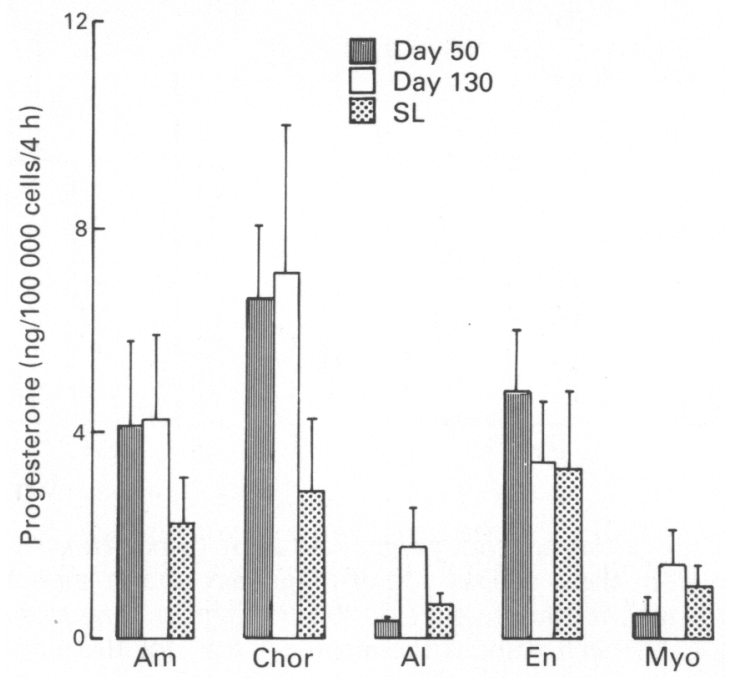

Fig. 4. The output of progesterone from $20 \alpha$-dihydroprogesterone by dispersed cells from amnion (Am), chorion (Chor), allantois (Al), endometrium (En) and myometrium (Myo) from sheep at Days 50 and 130 of pregnancy and at the time of spontaneous labour (SL). All values are mean \pm s.e.m. for the number of observations indicated in the text.
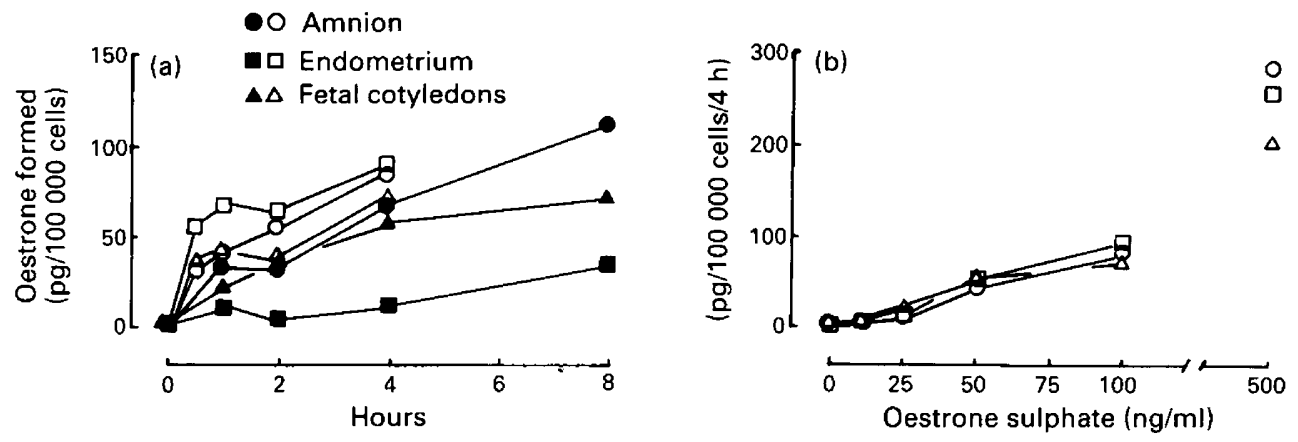

Fig. 5. The net accumulation of oestrone (a) with time after addition of $100 \mathrm{ng}$ oestrone sulphate/ $\mathrm{ml}$ and (b) with various substrate (oestrone sulphate) concentrations during 4-h incubation. Experiments were performed with dispersed cells from amnion, endometrium and fetal cotyledons from each of 2 sheep (solid and open symbols respectively). Each point is the mean of quadruplicate observations. The s.e.m. values are omitted for clarity, but in general were within the figure size of the datum points. Oestrone formation from increasing amounts of oestrone sulphate by Sheep 2 (solid symbols) gave results that were superimposable on those from Sheep 1 and are not included in the figure.

\section{Output of oestrogens}

There was no net output of oestrone or oestradiol-17 $\beta$ from endogenous precursors at any gestational age. Dispersed cells from amnion, endometrium and fetal cotyledons converted oestrone sulphate to oestrone in a time- and dose-dependent fashion (Fig. 5). For comparative purposes, all other incubations were carried out for $4 \mathrm{~h}$ in the presence of $100 \mathrm{ng}$ oestrone sulphate $/ \mathrm{ml}$ as substrate. Cells from the fetal membranes, endometrium and myometrium converted oestrone sulphate to oestrone at each time in pregnancy (Fig. 6), and the conversion was 


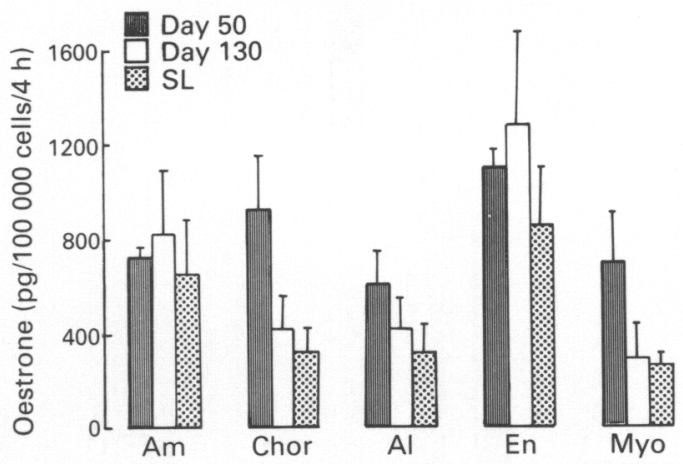

Fig. 6. The net output of oestrone from oestrone sulphate by dispersed cells from amnion (Am), chorion (Chor), allantois (Al), endometrium (En) and myometrium (Myo) from sheep at Days 50 and 130 of pregnancy and at the time of spontaneous labour (SL). All values are mean\pm s.e.m. for the number of observations indicated in the text.

Table 2. ${ }^{3} \mathrm{H}:{ }^{14} \mathrm{C}$ ratios in successive recrystallizations $\left(\mathrm{X}_{1}, \mathrm{X}_{2}, \mathrm{X}_{3}\right)$ of oestrone formed from oestrone sulphate at term

\begin{tabular}{lcccc}
\hline & \multicolumn{4}{c}{${ }^{3} \mathrm{H}:{ }^{14} \mathrm{C}$} \\
\cline { 2 - 5 } Tissue & t.l.c. & $\mathrm{X}_{1}$ & $\mathrm{X}_{2}$ & $\mathrm{X}_{3}$ \\
\hline Chorion & 0.404 & 0.281 & 0.275 & 0.280 \\
Endometrium & 0.489 & 0.373 & 0.361 & 0.331 \\
Amnion & 0.996 & 0.690 & 0.621 & 0.613 \\
Allantois & 1.014 & 0.690 & 0.601 & 0.609 \\
Myometrium & 0.426 & 0.213 & 0.177 & 0.205 \\
\hline
\end{tabular}

similar for each tissue at Day 50 of gestation. However, at Day 130 and at term, the conversion of oestrone sulphate to oestrone was significantly greater in amnion and endometrium than in chorion, allantois or myometrium $(P<0.05)$. Under the conditions of the present experiments, these differences were not observed for oestradiol- $17 \beta$ formation from oestrone sulphate, although oestradiol output was, in general, only $10-20 \%$ that of oestrone. We did not find any significant differences within any tissue for oestradiol output from oestrone sulphate as a function of gestational age (data not shown). In the chorion and myometrium, oestrone output from oestrone sulphate was significantly lower at term than at Day $50(P<0.05)$, although it was not significantly different from the conversion at Day $130(P>0 \cdot 05)$. There were no significant effects of gestational age on the oestrone sulphate to oestrone conversion by other tissues.

The conversion of $\left[{ }^{3} \mathrm{H}\right]$ oestrone sulphate to radioactivity corresponding to unconjugated oestrone was demonstrated for each tissue at each of the different times of gestation; the radiochemical purity of $\left[{ }^{3} \mathrm{H}\right]$ oestrone formed from $\left[{ }^{3} \mathrm{H}\right]$ oestrone sulphate by dispersed cells from all tissues obtained at term was confirmed by recrystallization (Table 2 ).

We were able to demonstrate aromatase activity (androstenedione to oestrone conversion) only in chorion with any consistency, and even in this tissue aromatase was present in cell preparations from most animals only at term (Fig. 7). The identity of oestrone formed from androstenedione was confirmed by the addition of $\left[{ }^{3} \mathrm{H}\right]$ oestrone to the samples, and by measuring the specific activity of the oestrone after extraction and without purification, and after extraction and purification by micro-celite chromatography. Values for specific activity were 2.50 and $2.27 \mathrm{c} . \mathrm{p} . \mathrm{m}$./pg 


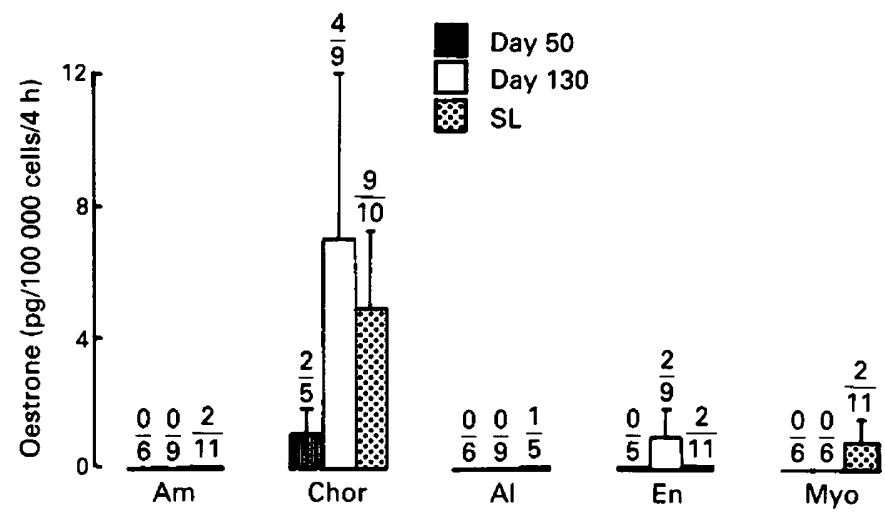

Fig. 7. The output of oestrone from androstenedione by dispersed cells from amnion (Am), chorion (Chor), allantois ( $\mathrm{Al}$ ), endometrium (En) and myometrium (Myo) from sheep at Days 50 and 130 of pregnancy, and at the time of spontaneous labour (SL). For each tissue the numerator is the number of tissues in which oestrone output was detectable. The denominator is the total number of tissues examined. The values shown are the mean \pm s.e.m. for those samples in which oestrone output was detected.

Table 3. Specific activity of radioactivity recrystallized with authentic steroid from ethanol with water

\begin{tabular}{lcrrrr}
\hline & & \multicolumn{4}{c}{ specific activity (c.p.m./mg) } \\
\cline { 3 - 6 } Tissue & \multirow{2}{*}{ Steroid* } & \multicolumn{1}{c}{ t.l.c. } & \multicolumn{1}{c}{$\mathrm{X}_{1}$} & \multicolumn{1}{c}{$\mathrm{X}_{2}$} & \multicolumn{1}{c}{$\mathrm{X}_{3}$} \\
\hline Chorion & $20 \alpha$-DHP & $763 \cdot 9$ & $489 \cdot 7$ & $515 \cdot 8$ & $467 \cdot 5$ \\
Endometrium & $20 \alpha$-DHP & $1174 \cdot 1$ & $935 \cdot 2$ & $1095 \cdot 3$ & $965 \cdot 8$ \\
Amnion & $20 \alpha$-DHP & $211 \cdot 0$ & $80 \cdot 5$ & $85 \cdot 3$ & $71 \cdot 2$ \\
Allantios & $20 \alpha-\mathrm{DHP}$ & $232 \cdot 9$ & $134 \cdot 5$ & $131 \cdot 5$ & $133 \cdot 2$ \\
Chorion & $17 \alpha-\mathrm{P}_{4}$ & $877 \cdot 6$ & $623 \cdot 1$ & $608 \cdot 2$ & $569 \cdot 5$ \\
\hline
\end{tabular}

${ }^{*} 20 \alpha$-DHP $=20 \alpha$-dihydroprogesterone; $17 \alpha-\mathrm{P}_{4}=17 \alpha$-hydroxyprogesterone.

without or with chromatographic purification respectively, supporting the authenticity of the measurements of product oestrone.

\section{Metabolism of $\left[^{3} \mathrm{H}\right]$ progesterone}

After incubation with $\left[{ }^{3} \mathrm{H}\right]$ progesterone, $\sim 50 \%$ of the radioactivity remained as progesterone in the different tissues. There was significant conversion to more polar compounds, especially in chorion and endometrium at Day 50 and Day 130 of gestation. On t.l.c. in the system chloroform:diethylether $(10: 3 \mathrm{v} / \mathrm{v})$ a major peak of radioactivity with an $R_{\mathrm{F}}$ value similar to monohydroxylated products was identified. After elution and HPLC, this material had a retention time that corresponded to $20 \alpha$-dihydroprogesterone. Smaller amounts of radioactivity from chorion chromatographed on HPLC in a position that corresponded to $17 \alpha$-hydroxyprogesterone. Confirmation was obtained for the radiochemical purity of $\left[{ }^{3} \mathrm{H}\right] 17 \alpha$-hydroxyprogesterone formed from $\left[{ }^{3} \mathrm{H}\right]$ progesterone by chorionic cells, and of $\left[{ }^{3} \mathrm{H}\right] 20 \alpha$-dihydroprogesterone formed from $\left[{ }^{3} \mathrm{H}\right]$ progesterone by dispersed cells from amnion, chorion, allantois and endometrium by recrystallization with authentic steroid (Table 3). 


\section{Discussion}

The present study has demonstrated a tissue-specific distribution of different steroid metabolic and synthetic enzyme activities in the amnion, chorion, allantois, endometrium and myometrium from sheep at various times during pregnancy. We found that progesterone was formed from $20 \alpha-$ dihydroprogesterone by all tissues at all three times studied, whereas $3 \beta-\mathrm{HSD}$ activity for progesterone output predominated in chorion and endometrium. All tissues exhibited oestrone sulphatase and $17 \beta$-oxidoreductase activity allowing oestrone and oestradiol formation. Oestrogen synthesis from androstenedione was minimal, and was confined to chorion. Even in the chorion, aromatase was demonstrable with consistency only in tissues collected at term. Using dispersed cells in vitro we have been unable to demonstrate significant changes in any of these enzyme activities between Day 130 of pregnancy and term.

The present studies demonstrate the potential for precursor uptake and interconversion by intact cell preparations, in agreement with previous studies using tissue homogenates or subcellular preparations. If the conversions we describe are to have physiological relevance in vivo, then it was necessary to demonstrate that intact cells, rather than just subcellular fractions were able to utilize potential substrates. It is recognized that limitations of precursor and co-factor availability preclude calculation of enzyme kinetic parameters. However, in experiments with the term tissue, progesterone and oestrone formation was dependent on time and on the concentration of substrate. Further, using similar techniques we reported that dispersed chorion and decidual cells obtained from women after spontaneous labour had an increased ability to convert oestrone sulphate to oestrone (Mitchell et al., 1984), compared to cells prepared from Caesarean section tissue. These results predicted the observation that oestrone sulphatase activity $\left(V_{\max }\right)$ was higher in subcellular preparations of membranes obtained at spontaneous labour (Chibbar et al., 1986). There is therefore good reason to suggest that the results of the present study might reflect enzyme activities at different gestational ages. The lack of change in substrate conversions in vitro, however, does not preclude local alterations in product formation in vivo, as the supply of steroid substrate alters during pregnancy. Further, the cells in vitro are removed from any endogenous modulators of enzyme activities, including steroids, that might have a systemic or local origin, and act in an acute manner in vivo during pregnancy.

Using tissue homogenates we have reported previously that $3 \beta-\mathrm{HSD}$ is present in the sheep

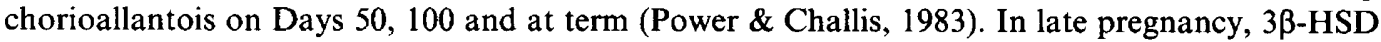
activity in the chorioallantoic membrane was similar to that in the fetal placenta, and was significantly greater than that in the amnion. A similar difference in the activities of chorion and amnion is apparent in the present study. In term tissue, from 2 animals, the formation of progesterone from pregnenolone by the endometrium was similar to that in cells from the fetal cotyledons, although greater than that by chorion cells. It is possible that other metabolites are formed from pregnenolone which affect the net conversion to progesterone (Marcus et al., 1979), although this was not suggested by our earlier studies (Power \& Challis, 1983). In man, 3 $\beta$-HSD is also low in amnion, and there is significantly greater $3 \beta$-HSD activity in chorion and decidua (Gibb et al., 1978, 1985; Mitchell et al., 1982). The conversion of exogenous pregnenolone to progesterone was higher in decidua obtained at Caesarean section than from patients at spontaneous labour (Mitchell et al., 1987), which could contribute to a local decrease in progesterone production in decidua at the time of labour in women. Evidence for similar changes was not obtained in the sheep.

$20 \alpha$-Dihydroprogesterone was a better substrate than pregnenolone for progesterone output at all stages of gestation by all tissues in the sheep. It is likely that $20 \alpha$-dihydroprogesterone is also more available as a substrate in vivo (Elsner et al., 1980). The human is similar to the sheep in these respects. Human amnion utilizes $20 \alpha$-dihydroprogesterone more effectively than pregnenolone for progesterone formation, although its activity is less than that of the chorion (Powell \& Challis, 1986; Mitchell et al., 1987). Progesterone is also metabolized to $20 \alpha$-dihydroprogesterone by human chorion, and this conversion is inhibited in the presence of excess product (Powell \& 
Challis, 1986). Chorion cells obtained from sheep in early gestation possess substantial ability to metabolize progesterone, including 20 $\alpha$-HSD activity (Marcus et al., 1979).

The present study provides conclusive evidence for the formation of radiochemically-pure $20 \alpha-$ dihydroprogesterone from progesterone by amnion, chorion, allantois and endometrium obtained at term. Evidence was obtained using HPLC which would be consistent with $20 \alpha$-HSD activity throughout pregnancy in these tissues, although recrystallization at each gestational age would be necessary to confirm the identity of the product. In addition, this study demonstrates that $17 \alpha$ hydroxylase activity is present in chorion cells from term animals. $17 \alpha$-Hydroxylase activity increases in the sheep placenta at term under the influence of fetal cortisol (Flint et al., 1975). Further studies would be required to examine the activity and regulation of $17 \alpha$-hydroxylase in chorion throughout pregnancy. However, because term chorion cells could also convert androstenedione to oestrone, the possibility is raised that this tissue at term has the full metabolic potential to utilize pregnenolone for oestrogen production.

Oestrogens (oestrone, oestradiol) were formed from oestrone sulphate by all tissues at the three stages of pregnancy. Some oestrone was formed from androstenedione by chorion, although quantitatively this conversion was substantially less than that through oestrone sulphatase activity. Confirmation of oestrone sulphatase was provided by recrystallizing oestrone from radioactive oestrone sulphate added to cell preparations of all tissues at term. Dwyer \& Robertson (1980) showed that oestrone sulphatase and sulphotransferase activities were present in the endometrium of pregnant sheep. Sulphatase activity decreased from early pregnancy to Day 90 , but no values were included at time points between Day 90 and a single high value at term that would allow comparison with the present results. We performed incubations in which oestrone sulphate was added to cells dispersed from the endometrium and amnion, and oestrone output was compared to that in similar incubations with dispersed placental cells. The formation of oestrone from oestrone sulphate at different substrate concentrations or with time suggested that in general this conversion was similar in the amnion and fetal cotyledons to that in the endometrium. The pattern of oestrone sulphatase activity in sheep tissues is apparently different from that in women. Human amnion, chorion and decidua obtained in late pregnancy all exhibit phenolic steroid sulphatase activities (Mitchell et al., 1984; Milewich \& Garcia, 1985). However, the formation of oestrone and oestradiol from oestrone sulphate is significantly greater in chorion and decidua than in amnion, and is higher after spontaneous labour than at elective Caesarean section at term (Mitchell et al., 1984; Chibbar et al., 1986). No similar changes were seen in sulphohydrolase activity for dehydroepiandrosterone sulphate. These observations supported the hypothesis that changes in oestrone and oestradiol production might occur within the fetal membranes and decidua of women at the time of labour. Although our present results do not support the occurrence of similar mechanisms in sheep, it must be remembered that the concentration of oestrone sulphate in ovine maternal plasma increases substantially during late pregnancy (Tsang, 1974). Increased precursor could provide more substrate and effect a local increase in oestrogen production and concentration (Power \& Challis, 1987b). In addition to any relationship at the onset of labour, oestrogens have been implicated in the regulation of the fetal fluid volumes (Wintour et al., 1986). The high oestrone sulphatase activity, and the relatively high oestrogen concentrations in the fetal membranes throughout gestation of the sheep might be important in this respect.

Aromatase activity was demonstrable only in chorion from Day 130 and term pregnant sheep. In women, aromatase activity is present in the fetal membranes (Gibb \& Lavoie, 1981), although the activity in chorion and amnion is substantially higher during the first trimester of pregnancy than at term (Siiteri \& Seron-Ferre, 1981). Therefore, in women and sheep it is likely that changes in aromatase activity are of relatively minor importance compared to those in phenolic steroid sulphatase in the production of oestrogens in the fetal membranes and endometrium.

In women, changes in enzyme activities in the intrauterine tissues, especially the chorion and decidua, occur during late pregnancy, and suggest the possibility of local steroid changes as causal events leading to parturition. The changes in enzyme activity at term occur in the absence of signifi- 
cant alterations in the systemic concentrations of progesterone or oestrogens. In sheep, however, circulating oestrogen and progesterone concentrations do change in late pregnancy, and several studies have suggested a role for systemic steroids in affecting myometrial contractility. The present studies indicate clearly the potential for steroid production in the fetal membranes, endometrium and myometrium of pregnant sheep, and raise the possibility of local modulation of steroid production by these tissues in vivo. However, we did not find significant changes in the steroid interconversions measured in the present study with cells obtained at term, under conditions where an increase in oestrone sulphatase has been reported with human tissues (Mitchell et al., 1984). Therefore, this study would not support the hypothesis that alterations in steroidogenic enzyme activities in the fetal membranes at term occupy a major place in the sequence of events leading to parturition in sheep.

We thank Dr Ronald Hobkirk (Department of Biochemistry, U.W.O.) for the gift of oestrone sulphate, and Lori Power and Nan Cumming for help in the preparation of this manuscript. This work was supported by the Medical Research Council of Canada (Group Grant in Reproductive Biology, J.R.G.C; Studentship, S.G.A.P.).

\section{References}

Chibbar, R., Hobkirk, R. \& Mitchell, B.F. (1986) Sulfohydrolase activity for estrone sulfate and dehydroepiandrosterone sulfate in human fetal membranes and decidua around the time of parturition. J. clin. Endocr. Metab. 62, 90-94.

Dwyer, R.J. \& Robertson, H.A. (1980) Oestrogen sulphatase and sulphotransferase activities in the endometrium of the sow and ewe during pregnancy. $J$. Reprod. Fert. 60, 187-191.

Elsner, C.W., Magyar, D.M., Fridshal, D., Eliot, J., Klein, J., Glatz, T., Nathanielsz, P.W. \& Buster, J.E. (1980) Time-trend analysis of plasma C-21 steroids in fetal and maternal sheep during the last 18 days of gestation. Endocrinology 107, 801-808.

Flint, A.P.F., Anderson, A.B.M., Steele, P.A. \& Turnbull, A.C. (1975) The mechanism by which foetal cortisol controls the onset of parturition in sheep. Biochem. Soc. Trans. 3, 1189-1194.

Gibb, W. \& Lavoie, J.C. (1981) Steroid aromatization by term human fetal membranes. J. Steroid Biochem. 141, 401-403.

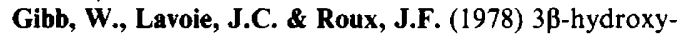
steroid dehydrogenase activity in fetal membranes. Steroids 32, 365-372.

Gibb, W., Lavoie, J.C. \& Morin-Gonthier, M. (1985) Kinetic comparison of the $3 \beta$-hydroxysteroid dehydrogenase activity in human placenta, chorion laeve and ovary. Can. J. Biochem. Cell. Biol. 63, 183-186.

Lye, S.J., Sprague, C.L., Mitchell, B.F \& Challis, J.R.G. (1983) Activation of ovine fetal adrenal function by pulsatile or continuous administration of adrenocorticotropin-(1-24). I. Effects on fetal plasma corticosteroids. Endocrinology 113, 770-776.

Marcus, G., Lucis, R. \& Ainsworth, L. (1979) Metabolism of progesterone by chorionic cells of the early sheep conceptus in vitro. Steroids 34, 807-815.

Milewich, L. \& Garcia, R.L. (1985) Steroid sulfatase activity in amnion tissue and amnion cells maintained in monolayer culture. J. clin. Endocr. Metab. 61, $812-816$.
Mitchell, B.F., Cruikshank, B., McLean, D. \& Challis, J. (1982) Local modulation of progesterone production in human fetal membranes. J. clin. Endocr. Metab. 55, 1237-1239.

Mitchell, B.F., Cross, J., Hobkirk, R. \& Challis, J.R.G. (1984) Formation of unconjugated estrogens from estrone sulphate by dispersed cells from human fetal membranes and decidua. J. clin. Endocr. Metab. 58, 845-849.

Mitchell, B.F., Challis, J.R.G. \& Lukash, L. (1987) Progesterone synthesis by human amnion, chorion and decidua at term. Am. J. Obstet. Gynecol. 157 (in press).

Nancarrow, C. \& Seamark, R.F. (1968) Progesterone metabolism in fetal blood. Steroids 12, 367-380.

Olson, D.M., Lye, S.J., Skinner, K. \& Challis, J.R.G. (1984) Early changes in prostaglandin concentrations in ovine maternal and fetal plasma, amniotic fluid and from dispersed cells of intrauterine tissues before the onset of ACTH-induced pre-term labour. $J$. Reprod. Fert. 71, 45-55.

Powell, W.A. \& Challis, J.R.G. (1986) Influence of $20 \alpha$-dihydroprogesterone on progesterone output by human chorion explants. Gynecol. Obstet. Invest. 22, 73-78.

Power, S.G.A. \& Challis, J.R.G. (1983) Activity of $3 \beta$ hydroxysteroid dehydrogenase-5,4-en isomerase in chorioallantois and amnion from pregnant sheep. $J$. Endocr. 97, 347-356.

Power, S.G.A. \& Challis, J.R.G. (1987a) The effects of gestational age and of intra-fetal ACTH administration on the concentration of progesterone in the fetal membranes, endometrium and myometrium of pregnant sheep. Can. J. Physiol. Pharmacol. 65, 136140.

Power, S.G.A. \& Challis, J.R.G. (1987b) Tissue-specific concentration changes of estrone and estradiol during spontaneous and ACTH-induced parturition in sheep. Can. J. Physiol. Pharmacol. 65, 130-135.

Rossier, G. \& Pierrepoint, C.G. (1974a) Oestrogen 
metabolism in the sheep myometrium. J. Reprod. Fert. 37, 43-49.

Rossier, G. \& Pierrepoint, C.G. (1974b) The in vitro metabolism of $\mathrm{C}_{21}$ - and $\mathrm{C}_{19}$-steroids by pregnant sheep myometrium. J. Reprod. Fert. 36, 169-176.

Siiteri, P.K. \& Seron-Ferre, M. (1981) Some new thoughts on the feto placental unit and parturition in primates. In Fetal Endocrinology, pp. 1-34. Eds M. J. Novy \& J. A. Resko. Academic Press, London.

Thorburn, G.D. \& Challis, J.R.G. (1979) Endocrine control of parturition. Physiol. Rev. 59, 863-918.
Tsang, C.P.W. (1974) Changes in plasma levels of estrone sulfate and estrone in the pregnant ewe around parturition. Steroids 23, 855-868.

Wintour, E.M., Laurence, B.M. \& Lingwood, B.E. (1986) Anatomy, physiology and pathology of the amniotic and allantoic compartments in the sheep and cow. Aust. vet. J. 63, 216-221.

Received 19 December 1986 